\title{
Accelerating Silphium Domestication: An Opportunity to Develop New Crop Ideotypes and Breeding Strategies Informed by Multiple Disciplines
}

\author{
David L. Van Tassel,^ Kenneth A. Albrecht, James D. Bever, Arvid A. Boe, Yaniv Brandvain, Timothy E. Crews, Markus \\ Gansberger, Pedro Gerstberger, Luciana González-Paleo, Brent S. Hulke, Nolan C. Kane, Paul J. Johnson, Elena G. \\ Pestsova, Valentín D. Picasso Risso, Jarrad R. Prasifka, Damian A. Ravetta, Brandon Schlautman, \\ Craig C. Sheaffer, Kevin P. Smith, Pablo R. Speranza, M. Kathryn Turner, Alejandra E. Vilela, \\ Philipp von Gehren, and Christian Wever
}

\begin{abstract}
Silphium perfoliatum L. (cup plant, silphie) and S. integrifolium Michx. (rosinweed, silflower) are in the same subfamily and tribe as sunflower (Helianthus annuus L.). Silphium perfoliatum has been grown in many countries as a forage or bioenergy crop with forage quality approaching that of alfalfa (Medicago sativa L.) and biomass yield close to maize (Zea mays L.) in some environments. Silphium integrifolium has large seeds with taste and oil quality similar to traditional oilseed sunflower. Silphium species are all long-lived, diploid perennials. Crops from this genus could improve the yield stability, soil, and biodiversity of agricultural landscapes because, in their wild state, they are deep rooted and support a wide diversity of pollinators. In contrast with premodern domestication, de novo domestication should be intentional and scientific. We have the luxury and obligation at this moment in history to expand the domestication ideotype from food and energy production to include (i) crop-driven ecosystem services important for sustainability, (ii) genetic diversity to enable breeding progress for centuries, (iii) natural adaptations and microbiome associations conferring resource use efficiency and stress tolerance, and (iv) improving domestication theory itself by monitoring genetic and ecophysiological changes from predomestication baselines. Achieving these goals rapidly will require the use of next-generation sequencing for marker development and an international, interdisciplinary team committed to collaboration and strategic planning.
\end{abstract}

D.L. Van Tassel, T.E. Crews, B. Schlautman , and M.K. Turner, The Land Institute 2440 E Water Well Rd., Salina, KS 67448; K.A. Albrecht and V.D. Picasso Risso, Dep. of Agronomy, Univ. of WisconsinMadison, 1575 Linden Dr., Madison, WI; A.A. Boe, Plant Science, South Dakota State Univ., Box 2140C, Brookings, SD 57007; J.D. Bever, Univ. of Kansas, 1200 Sunnyside Ave., Lawrence, KS 66045; Y. Brandvain, Dep. of Plant Biology, Univ. of Minnesota 232 Cargill Building 1500 Gortner Ave., St. Paul, MN 55108; M. Gansberger and P. von Gehren, Austrian Agency for Health and Food Safety (AGES) Spargelfeldstraße 191 1220, Wien, Austria; P. Gerstberger, Dep. of Plant Ecology, Univ. of Bayreuth, Post Box 1012 51, D-95448 Bayreuth, Germany; L. GonzálezPaleo, D.A. Ravetta, and A.E. Vilela, National Scientific and Technical Research Council (MEF-CONICET), Fontana 140, Trelew, Chubut, Argentina; B.S. Hulke and J.R. Prasifka, Northern Crop Science Laboratory, USDA-ARS 1307 18th St. N. Fargo, ND 58102; N.C. Kane, Ecology and Evolutionary Biology, Univ. of Colorado, 1900 Pleasant St. 334, UCB Boulder, CO 80309-0334; P.J. Johnson, Insect Biodiversity Laboratory Box 2207A, Brookings, SD 57007; C.C. Sheaffer and K.P. Smith, Dep. of Agronomy and Plant Genetics, Univ. of Minnesota, 411 Borlaug Hall 1991 Upper Buford Circle, St. Paul, MN55108; P.R. Speranza, Faculty of Agronomy, Univ. of the Republic, Garzón 780, 12900, Montevideo, Uruguay; E.G. Pestsova and C. Wever, Institute of Developmental and Molecular Biology of Plants, Heinrich-Heine-Univ. Universitaetstr. 1, Geb. 26.03.02 40225 Düsseldorf, Germany. Received 1 Oct. 2016. Accepted 16 Mar. 2017. ^Corresponding author (dlvantassel@, gmail.com). Assigned to Associate Editor Dina St. Clair.

Abbreviations: GWAS, genomewide association study; NGS, nextgeneration sequencing.

$\mathrm{P}$ REHISTORIC domestication proceeded by ongoing conscious and unconscious human selection, driven by the seed-dispersing behavior of humans attempting to secure short-term survival (Diamond 2002). Thanks to them and modern plant breeders, there is currently unprecedented production of grain,

Published in Crop Sci. 57:1274-1284 (2017).

doi: 10.2135/cropsci2016.10.0834

(C) Crop Science Society of America 5585 Guilford Rd., Madison, WI 53711 USA This is an open access article distributed under the CC BY-NC-ND license (http://creativecommons.org/licenses/by-nc-nd/4.0/). 
which temporarily provides us the opportunity to critically evaluate the results of past domestication and to plan for long-term human survival. Although our understanding of plant physiology, the plant microbiome, evolution, and genetics, coupled with the development of powerful new sequencing and gene-editing techniques, allows us unprecedented opportunities to characterize our crops' genepools and accelerate ongoing crop improvement, today's food crops are committed to a narrow range of evolutionary trajectories. For both biological reasons (polyploidy, extinct ancestors, narrowed gene pools, developmental canalization) and cultural or economic reasons (commodity standards, farmer traditions, consumer expectations), it would be very difficult to substantially reshape these crops to perform new ecosystem services or to thrive in very different environments (Sharma et al., 2002; Rozema and Flowers, 2008; Juenger, 2013).

If we could imagine an idealized case where humanity could start from scratch and conduct domestication from a scientific, long-term perspective, unconstrained by political pressure for rapid financial return on research investment, the needs of agricultural constituents, or the burden of feeding today's hungry, what would we do differently? Would we want to recreate crops functionally identical to our current major crops, or would the dramatically different situation that humanity finds itself in now, compared with $10,000 \mathrm{yr}$ ago, require new ideotypes or, at least, new expectations for the genetic structure and diversity of the crop and its genepools? Would we select from populations developed with time-proven methods of crossing "good with good?" Alternatively, could more precise breeding enabled by modern genomics allow for trait improvement with minimal linkage drag and, consequently, minimal loss of genetic variation through selective sweeps and population bottlenecks? Perhaps breeders may be able to select alleles with minimal undesirable pleiotropic effects? In the case of a closely related species, sunflower (Helianthus annuus L.), domestication was the result of the selective sweeping around many domestication loci, some very large, which perhaps unnecessarily put constraints on genetic diversity of modern germplasm (Mandel et al., 2013; Baute et al., 2015). Therefore, well-planned methods of domestication are warranted; general strategies for domestication and prioritization of candidates have been recently proposed (DeHaan et al., 2016).

As an example of a revision of the previous ideotypes for both new grain and biofuel crops, the perennial habit has been proposed as a major improvement over the annual habit that characterizes the majority of our current staple food and energy crops (Sanderson and Adler, 2008; Glover et al., 2010; Kantar et al., 2016). Breeding perennials for increased allocation to sink structures such as stalks and seeds may reduce their fitness in unmanaged plant communities and reduce their longevity (González-Paleo and Ravetta, 2011), although DeHaan et al. (2005) argued that a reduction from a lifespan of hundreds to tens of years might be acceptable. The current deficit of high-yielding herbaceous perennial crops may be better explained by noting that species-rich, human-managed perennial crop fields represent a new environment to which no existing species are adapted (Crews and DeHaan 2015), rather than invoking the impossibility of plants employing two categorical adaptive strategies at the same time (Smaje, 2015). Perennialism in plants is also something of a "gateway" character that opens the door to botanical morphospace previously underused by agriculture (Van Tassel et al., 2010). If we had the chance to start again, would we want to try to take advantage of some of the biochemical pathways, leaf and root architectures, environmental adaptations, and defense mechanisms contained in that untapped space? Perennialism also allows for agricultural exploitation of desirable soil conditions, both physical and biological, that are more typically associated with natural grassland or other wild ecosystems (Crews et al., 2016).

We have a unique opportunity to try de novo domestication as rationally as possible. Two species of a North American prairie genus, Silphium, have been proposed as new crops. The present authors have agreed to work together, sharing germplasm and expertise and coordinating strategically on new experiments. We briefly review the features of Silphium that make it suitable as a test case for "next-generation domestication" and then outline our ideas of what that means and how new approaches and tools may make it possible.

\section{SILPHIUM AS A BLANK SLATE FOR DE NOVO DOMESTICATION}

Silphium, a genus in the same tribe (Heliantheae) of the Asteraceae as Helianthus (Clevinger and Panero, 2000), was noted by North American ecologists and conservationists in the 1930s and 40s for the ability of several of its species to tolerate many kinds of stress, including the droughts of the Dust Bowl period (Weaver et al., 1935; Leopold, 1968). Silphium species have been proposed for bioremediation of soils contaminated with crude oil or copper-mine tailings (Zhang et al., 2006, 2011) and revegetation of eroded, acidic landscapes in Southern China (Ouyang et al., 2007). These reports suggest broad adaptation and tolerance to general abiotic stresses.

\section{Economic Botany}

The resinous sap characteristic of the genus (Bare, 1979) may have been used as chewing gum by Native Americans and the roots as medicine (Stanford, 1990). Although Leopold (1968) noted that cattle preferentially grazed the foliage and that the seeds tasted like sunflower seeds, it was USSR scientists who first attempted to exploit the genus as a forage crop beginning in 1957 (Stanford, 1990). Experimental plots of $S$. perfoliatum L. have subsequently 
been grown in several European countries, China, Japan, Chile, and the United States since that time (Stanford, 1990; Gansberger et al., 2015), but largescale commercial use has not been reported.

Experimental plots of S. integrifolium Michx. have been grown in Kansas and independently in Poland since the early 2000s (Kowalski and Wiercinski, 2004; Van Tassel et al., 2014), and more recently, plots have been established in Wisconsin, Minnesota, North Dakota, Texas, Vermont, Uruguay, and Argentina. Whereas S. perfoliatum has always been considered as a potential forage or bioenergy crop (Han et al., 2000a, 2000b; Lehmkuhler et al., 2007), S. integrifolium has been considered as a potential new oilseed because its fatty acid profile is similar to the oilseed sunflower (Kowalski and Wiercinski, 2004; Van Tassel et al., 2014). However, no commercial production has been initiated, reflecting the lack of improved cultivars and the many processing and marketing difficulties faced by new crops (Raymer, 2002).

\section{Genetics}

All Silphium species are diploids, with seven pairs of chromosomes, but have roughly 2.5 times the genome size of sunflower $(2 \mathrm{C}=16.6-16.9 \mathrm{pg}$ ) (Bai et al., 2012, Supplemental Table S1). Molecular data have only been used for establishing the phylogenetic relationships within the genus and subtribe (Clevinger and Panero, 2000), but otherwise both genomic organization and the population genetic structure of these species remain unknown. Both S. perfoliatum and S. integrifolium cluster in the same subclade of the genus (Clevinger and Panero, 2000) and can be crossed with normal pairing (Settle, 1967). Spontaneous hybrids are known (Yatskievych, 2006), although such hybrids have reduced fertility (Van Tassel, unpublished data, 2016). It remains to be seen if interspecific $F_{1}$ cultivars or stable allopolyploids could be viable options for combining the agronomic traits from different Silphium species. At the minimum, it seems likely that $S$. perfoliatum and $S$. integrifolium can be sources of alleles for each other using introgression breeding.

\section{Plant Breeding}

Exploratory genetic research has demonstrated heritable variation for traits of interest in both cases (Van Tassel et al., 2014; Assefa et al., 2015). Breeding populations of $S$. integrifolium have been developed with increased numbers of seeds per head, through selection for (pistillate) ray florets (Van Tassel et al., 2014). Several improved populations were developed in Russia and Ukraine in the past (Arkhipenko and Larina, 2011), but no well-documented and widely available cultivars or genetic stocks have been released in recent decades despite recent interest and expanding hectarage in Germany and farmer requests for further improvement (Pestsova, personal communication,
2016, 2017). Seed dormancy and seedling emergence and vigor are among the most limiting traits (Gansberger et al., 2015; Von Gehren et al., 2016).

\section{OPPORTUNITIES TO DO DOMESTICATION DIFFERENTLY}

Opportunities to accelerate domestication using next-generation sequencing (NGS)-based techniques and insights from decades of advances in evolutionary biology have been reviewed elsewhere (Harfouche et al., 2012; Henry, 2012; Shapter et al., 2013; DeHaan and Van Tassel, 2014). If Silphium represents a new opportunity to do better than our ancient ancestors, we suggest that rational, intentional domestication requires us to consider not just why to use perennials or how to do it faster, that is, how to efficiently increase yields and make the crop easier to harvest, use, and propagate, but how a newly domesticated crop might be intentionally developed anticipating the stages of crop research and use after domestication. The challenge of new perennial breeding programs will be to maintain those traits associated with the perennial habit and the provision of ecosystem services while increasing yield potential and stability (Vico et al., 2015).

\section{Improved Capacity for Delivering Specific Ecosystem Services}

As the matrix of native vegetation declines in agricultural regions, agroecologists are attempting to design agricultural landscapes where the crops themselves drive necessary ecosystem processes (Power, 2010; Asbjornsen, 2013; Runck et al., 2014). Because many wild perennial plants may help stabilize soil and sequester carbon, the baseline allocation patterns and the morphological and functional traits that provide those and other types of services of domestication candidates should be described in their predomesticated state. Understanding wild candidates in their ecosystem context, including successional state and soil development, is also germane to the delivery of services, especially those associated with the soil microbiome (Koziol and Bever, 2015). The causal relationships between plant form and function and scalable services must be investigated to help us track changes in key traits at the same time that we determine if they are compromised during domestication, and to do our best to ensure that they are not. Since not every trait can be monitored, wild candidates should be assessed critically to prioritize the potential services in which they likely have a comparative advantage over other crops.

Silphium species are known to be mycorrhizal (Dhillion and Friese, 1992), deep rooted (Wynia, 2009), drought tolerant (Weaver et al., 1935; Ouyang et al., 2007), and to support populations of beneficial earthworms (Schorpp and Schrader, 2016) and a wide diversity of insects (Fiedler and Landis, 2007; Tuell et al., 2008), including natural 
pest enemies (Kula et al., 2017). Deep-rooted perennial bioenergy crops can restore water quality through phytoextraction of agrochemicals including nitrates (Ferchaud et al., 2016). Root architecture and mycorrhizal dependence can evolve rapidly as plants expand their range (Seifert et al., 2009). The potential benefits of drought avoidance, nitrate scavenging, and mycorrhizal associations make these obvious traits to monitor during domestication. Other examples of relevant characters we are looking at are those such as root, stem, and leaf anatomy and composition that influence soil organic matter formation. Changes in flowering phenology and pollen and nectar quantity and quality should be tracked. Silphium secondary metabolites (Jamiolkowska and Kowalski, 2012) are likely to influence its ecological impacts. Exactly which other services each Silphium crop would be designed to deliver and exactly which plant traits are required for fulfilling those services requires additional, ongoing research. Strategically chosen intercrops could provide some services currently provided by wild Silphium. Polyculture could therefore reduce the complexity of the domesticated Silphium ideotype relating to services but complicate it by adding requirements for interspecific facilitation or reduced competition.

We are committed to characterizing the wild plants and coevolved symbionts, mutualists, and community associates to more fully understand the strengths and weaknesses of these species with the goal of retaining traits that provide potential ecosystem services and confer Silphium a comparative advantage over other crops. Wild and selected candidates are being compared critically in Patagonia, where early observations suggest that leaf traits are already beginning to change as an unintended correlated response to selection for reproductive traits (Vilela, unpublished data, 2016). Negative correlations between yield components, classic domestication traits, and ecosystem service traits will slow breeding progress and need to be identified.

\section{Considering the Needs of Future Breeding Efforts}

The erosion of genetic diversity during the domestication and modern improvement of major crops threatens to limit the ability of breeders to further increase yields or adapt crops to new challenges. (Esquinas-Alcázar, 2005). Although conversion of native grasslands to farmland has undoubtedly caused the extinction of some local Silphium populations, nevertheless, S. integrifolium is currently found in 21 US states and S. perfoliatum in 31 states and two Canadian provinces (National Plant Data Team, 2016). Each can therefore be found in a large geographical region and comprise several recognized subclades. This, together with their longevity and strong self-incompatibility, leads us to predict that they are currently genetically diverse (J. Prasifka and B. Hulke, personal communication, 2016).
We plan to use three strategies to minimize the loss of genetic diversity during the domestication of Silphium. First, both European and North American researchers have already begun collecting seeds from wild populations throughout the range of both species to greatly diversify the breeding populations (Pestsova, 2015; C. Wever and Y. Brandvain, personal communication, 2016). Use of the collected materials within a collaboration among Silphium breeders and geneticists will allow for studies of Silphium genetic diversity and population structure similar to those recently performed in domestication efforts for the potential bioenergy crop Miscanthus (Clark et al., 2014, 2015) and, ultimately, to ensure that Silphium domestication begins with a broad base of genetically diverse germplasm from a wide geographic origin. Identifying a core collection (Brown, 1989) and understanding the genetic and phenotypic variation within it will help breeders prioritize crossing based on their needs at the time. Expanding this collaboration to physiologists and ecologists, using the collection in additional simultaneous studies of Silphium plant morphology and ecophysiology, and categorizing the ecological and environmental conditions of the collections sites is assisting in the development of ideotypes for Silphium and in predicting its potential areas of cultivation.

Additionally, sequencing and phenotyping samples from this population will allow for both gene-environment associations (Rellstab et al., 2015), and genomewide association studies (GWAS; Visscher et al., 2012) to identify loci of interest in a breeding program. Finally, a study of this sort could also provide valuable insights about the locations of unique Silphium diversity hotspots, which are candidates for in situ conservation efforts (Pavek et al., 2003; Meilleur and Hodgkin, 2004), or to strategically identify landscape positions or regions where novel variation may reside and where additional germplasm collection efforts should be focused (Reyno et al., 2012).

Second, frequent monitoring of the allelic richness of breeding populations can help minimize allele extinction by drift or hitchhiking through targeted enrichment strategies. Next-generation sequencing technologies are being used to generate genomewide marker datasets for $S$. integrifolium (Smith, unpublished data, 2016) and S. perfoliatum (Pestsova, unpublished data, 2016) that can assist in monitoring allele diversity and facilitate the use of large breeding populations (Allendorf et al., 2010).

Finally, in anticipation of some unavoidable narrowing of the genetic base of Silphium cultigens, we are preserving wild seed collections. Ex situ seed conservation has limitations (Simmonds, 1962), so we will also establish field gene banks, preferably in several locations, where the core collections will be allowed to undergo sexual reproduction (using controlled polycrossing to avoid intermating between accessions) every 3 to 5 yr. It is our view that it will be impossible-and undesirable - to prevent some 
natural and human-mediated selection from taking place. Indeed, one of the goals of maintaining these collections is to allow and encourage adaptation to evolving pests, pollinator support, and changing climate. Traits that will facilitate the use of these materials in future breeding programs will be gradually improved by culling plants with severe disease symptoms, lodging, or sterility.

\section{Breeding Specialized Cultivars to Design Profitable and Sustainable Cropping Systems}

Hasty domestication could result in the loss of potentially useful "wild traits" (Ladizinsky, 1985; Cowling et al., 2009) conferring biotic and abiotic stress tolerance or specialized resource-use or life-history strategies. Even in recently domesticated species, such as the American cranberry (Vaccinium macrocarpon Aiton), these wild traits were not monitored, and as a result, breeding activities have compromised necessary plant anti-herbivory defenses in commercial cranberry varieties (Rodriguez-Saona et al., 2011). Likewise, Benrey et al. (1998) found that Brassica and Phaseolus cultivated domesticates were more susceptible to phytophagous insects and parasitoids than their uncultivated wild brethren. On the other hand, native perennials may be surprisingly susceptible to native pests (Prasifka et al., 2012); pest tolerance alleles may be rare until strong directional, artificial selection increases their frequency. Therefore, it would also be hasty to reject candidate species or candidate functional traits after observing only a few individuals from unselected populations.

Wild Silphium germplasm is currently adapted to multiple latitudes and temperature regimes and has been noted to tolerate flooding (Stanford, 1990), wind, and drought (Weaver et al., 1935). As expected, Silphium species are not as water-use efficient as $\mathrm{C}_{4}$ grasses (Schoo et al., 2016), but they are likely to be more resource conservative than the ruderal ancestors of annual crops or perennial species strongly selected for rapid growth in resource rich environments (González-Paleo and Ravetta, 2011). The wild populations of both these Silphium species already show an ideotype of root architecture for drought resistance and nitrogen use efficiency, which was lost in several modern crops (Lynch 2013). It might therefore be possible to domesticate both "acquisitive" and "conservative" biotypes of Silphium species, which would be better adapted to high- and low-input systems, respectively. Likewise, we plan to develop breeding pools for several major geographic regions (cold temperate, subtropical, etc.). There is a particular advantage of breeding Silphium species in cold regions, since only a few $\mathrm{C}_{4}$ species can match the production of $\mathrm{C}_{3}$ crops in cooler environments (Friesen et al., 2015)

In their native range, both $S$. perfoliatum and $S$. integrifolium show signs of being unadapted to high-density monoculture, experiencing higher severity of insect herbivory and fungal disease than in native plant communities
(Johnson et al., 2012, Van Tassel et al., unpublished observations, 2016). In the short term, at least, breeding in and for "polyculture adaptation" can prioritize yield potential and harvestability, whereas breeding for monoculture must prioritize insect and disease tolerance or resistance before yield potential can be reliably measured.

In an effort to maintain the broad genetic base and potential adaptability of Silphium through domestication, selection, and commercial cultivation, we propose to complement (i) intensive selection for domestication traits, with (ii) parallel programs to develop populations with improved adaptation to new environments, and (iii) heterotic groups. Approach (ii) builds on the longterm introgression strategy proposed by Simmonds (1993) by using population-based approaches to maximize recombination in large, genetically diverse, and dynamic populations that gradually become adapted to target environments through epistasis and coadaptation of genes (Haussmann et al., 2004). A third set of genepools will be developed from the ex situ collection (again, in genetic isolation from each other) in approach (iii) to conserve genetic variation that contributes to heterosis. This variation could be lost in approach (ii), especially where previously isolated populations are deliberately composited or used only as sources of alleles for introgression into elite genetic backgrounds. After quantifying genetic distance using modern methods to understand baseline population structure, targeted biparental crosses, or reciprocal recurrent selection among the ex situ accessions will be performed to analyze, enforce, and enhance functional genetic divergence of heterotic pools (Saxena and Sawargaonkar, 2014; Boeven et al., 2016).

New ideotypes being developed at this early stage of new domestication could also include new options for achieving profitability. Silphium species have been found to contain a range of phytochemicals, some with agricultural or industrial possibilities, including antimicrobial activity (Jamiolkowska and Kowalski, 2012). Other products are being considered, including resins (Ravetta, unpublished data, 2016), paper (Wever, personal communication, 2016), and solid fuel briquettes (Wrobel et al., 2013).

\section{Providing Data and Theory for the Domesticators of Additional New Crops}

Like most of evolution, the evolution of our present crops took place as unique, historical events. Much can be inferred from archaeological and comparative genetic or genomic studies, but much is forever lost. With de novo domestication in the age of big data, gene editing, and NGS, we have the opportunity to more fully document the transition from wild plant to crop. Because these are long-lived and can be propagated vegetatively (Vilela, unpublished data, 2016), some of the ancestral individuals from various stages of domestication will be cloned and 
kept alive indefinitely, enabling future scholars to replicate particular stages of the process. Sequence and allele frequency data and dried tissue samples will also be archived.

Beyond archiving and documenting the process, we hope to conduct experimental domestication involving replicated populations and selection regimes. The fact that two closely related species from the same genus are being domesticated simultaneously offers an opportunity to compare their rate of morphological and genomic change and correlated responses to selection. At least two subspecies of both S. perfoliatum and S. integrifolium are recognized (The Plant List, 2013) and perhaps additional ecotypes or genetic clusters will be identified; we plan to use the independent selection schemes in approaches (i), (ii), and (iii) above to test hypotheses about the repeatability of genetic, physiological, and anatomical changes that are thought to be associated with domestication (GonzálezPaleo and Ravetta, 2012; González-Paleo et al., 2016). Using both genetic and morphological data from breeding populations during each generation of selection, we plan to perform selection signature studies to determine and compare the genomic locations under artificial selection for the two species (Prezeworski et al., 2005; Fontanesi et al., 2010; Wright et al., 2005). We imagine that such studies are of benefit not only to Silphium researchers, but also to a wider scientific audience interested in understanding the genetic basis of adaptation and domestication.

\section{NEXT-GENERATION DOMESTICATION}

Four general strategies recur when considering how to accomplish the goals described above. New technologies make each of these more feasible.

\section{Multiple Traits}

Next-generation ideotypes are more complex than the previous generation, requiring the selection of traditional yield and domestication syndrome traits while avoiding loss of desirable wild characters. Multiple-trait genomic selection using multivariate models that take advantage of the genetic covariance between traits provides a practical means of simultaneously selecting both wild and classical traits that make up next-generation ideotypes (Jia and Jannink, 2012). Some of the "wild traits" or classical traits may be difficult or expensive to measure, have low heritabilities, or may require too much time to measure. However, generating genomic selection prediction models and/or using highly heritable indicator traits (genetically correlated with the wild or difficult-to-measure traits) will facilitate selection progress without reallocating substantial amounts of resources (Cameron, 1997; Calus and Veerkamp, 2011). Moreover, multiple-trait genomic selection models likely have special utility for breeding and domesticating perennial wild plants that have a more complex life-cycle and morphology by improving selection accuracy and gain per unit time, which are generally limited by periods of juvenility, and by allowing for selection of traits related to longevity (Heffner et al., 2010; Resende et al., 2012; Desta and Ortiz, 2014; González-Paleo et al., 2016). On the other hand, some necessary domestication traits may have high heritability and simple genetics but are rare to discover in nature because they are unfit for natural environments. Monocephaly, nondormant seed, or male sterility are examples. Mutagenesis may allow for development of these phenotypes in a relatively small population of closely related plants, which should simplify deduction of causal mutants by genomic resequencing.

\section{Multiple Disciplines}

An interdisciplinary team is required to meet these objectives. In addition to colleagues in applied fields, plant pathologists, entomologists, agroecologists, agricultural economists, food or fuel chemists, and colleagues from the biology departments - those studying evolution, plant physiology, plant-microbe ecology-are crucial if we are to design a new kind of domestication and document our efforts for future researchers. Engineers and computer scientists have already begun tackling some of the logistical and technical challenges arising from working with oddly shaped seed and large breeding populations of perennials. Electronic communication, online databases, and even social media make this kind of collaboration much easier than in the past.

\section{Multiple Breeding Populations}

Strong, recurrent artificial selection on replicate small populations followed by hybridization to combine alleles from each selection regime has been proposed as a strategy for accelerating domestication while minimizing genetic erosion (DeHaan and Van Tassel, 2014). Natural selection acting on small, independently evolving populations can also be exploited to obtain adapted (but not necessarily domesticated) biotypes. Marker-assisted selection will be essential for rapidly eliminating linkage drag when introgressing traits of interest from one population to another. More broadly, this combination of sequence informed background selection, and the maintenance of numerous populations will allow us to minimize the loss of diversity linked to selected sites, which can occur via selective sweeps.

After developing the Silphium composite cross base domestication population by crossing genetically diverse accessions without selection (Allard, 1988), the seed will be distributed to collaborators in as many geographic locations as possible. Initially, indirect or natural selection will be dominate at the sites, although some direct selection for reduced stratification requirements, lodging resistance, and photoperiod responses may be required to retrieve seed each year from the population. Seed will be harvested from each site every 2 to $4 \mathrm{yr}$ and replanted at the same site. 


\begin{tabular}{|c|c|c|}
\hline Undomesticated ecotype & $\rightarrow \quad \begin{array}{c}\text { Cultivar with } \\
\text { ecosystem service traits }\end{array}$ & $\begin{array}{r}\text { "Over-domesticated" } \\
\text { cultivar }\end{array}$ \\
\hline $\begin{array}{l}\text { Low and/or variable whole-plant } \\
\text { harvest index }\end{array}$ & $\begin{array}{l}\text { Above-ground harvest index may approach that of } \\
\text { annual crops but large reduction in belowground } \\
\text { biomass could reduce survival and ecosystem services. }\end{array}$ & $\begin{array}{r}\text { High and consistent whole-plant } \\
\text { harvest index }\end{array}$ \\
\hline Very long lifespan & $\begin{array}{l}\text { Intermediate lifespan may provide acceptable services } \\
\text { and stand replacement may be necessary for long-term } \\
\text { crop rotation and to introduce improved cultivars. }\end{array}$ & Annual or short-lived perennial \\
\hline $\begin{array}{l}\text { Investment in traits to acquire } \\
\text { resources unavailable to most crops }\end{array}$ & $\begin{array}{l}\text { Diminishing returns on investment may justify } \\
\text { moderated acquisition e.g., of water from extreme } \\
\text { depth, photoenergy very late in the season, etc. }\end{array}$ & $\begin{array}{r}\text { Adapted to acquiring resources from a } \\
\text { more limited time and space }\end{array}$ \\
\hline $\begin{array}{l}\text { Adaptation to intraspecific } \\
\text { competition }\end{array}$ & $\begin{array}{l}\text { Intermediate reduction in plant height, spreading } \\
\text { roots, etc., allows increased yield per unit area without } \\
\text { excessively reducing competitiveness with weeds. }\end{array}$ & Intraspecific competition minimized \\
\hline $\begin{array}{l}\text { Many heads, numerous and complex } \\
\text { inflorescences, long flowering period }\end{array}$ & $\begin{array}{l}\text { High yield could be achieved with multiple heads per } \\
\text { stem but a reduction in the number of heads may be } \\
\text { necessary to achieve synchrony. }\end{array}$ & $\begin{array}{r}\text { Determinate, single-head, unbranched, } \\
\text { highly synchronized flowering }\end{array}$ \\
\hline $\begin{array}{l}\text { Seeds and heads adapted for efficient } \\
\text { dispersal }\end{array}$ & $\begin{array}{l}\text { Humans must take over the function of seed dispersal } \\
\text { for efficient harvesting. }\end{array}$ & $\begin{array}{r}\text { Completely non-shattering heads. } \\
\text { Loss of dispersal structures }\end{array}$ \\
\hline $\begin{array}{l}\text { Grain not suitable for processing with } \\
\text { standard equipment }\end{array}$ & $\begin{array}{l}\text { Difficulties in harvesting, cleaning, processing the } \\
\text { grain may prevent profitable adoption of the crop. }\end{array}$ & $\begin{array}{r}\text { Grains easy to process and } \\
\text { use commercially }\end{array}$ \\
\hline $\begin{array}{l}\text { Seed dormancy prevents germination } \\
\text { in unfavorable conditions }\end{array}$ & $\begin{array}{l}\text { Farmers can predict/create safe germination } \\
\text { conditions. Rapid, synchronous germination } \\
\text { facilitates weed control and a uniform stand. }\end{array}$ & $\begin{array}{r}\text { Rapid germination and } \\
\text { stand establishment }\end{array}$ \\
\hline $\begin{array}{l}\text { Ability to recover from severe damage } \\
\text { by rapid reallocation of reserves }\end{array}$ & $\begin{array}{l}\text { Intermediate resilience justified because frequency of } \\
\text { disturbances is lower in managed landscapes. }\end{array}$ & $\begin{array}{l}\text { Poor resilience to sudden stress due to } \\
\text { low reserves and reduced plasticity. }\end{array}$ \\
\hline $\begin{array}{l}\text { Physiological and morphological } \\
\text { adaptation for abiotic stress tolerance }\end{array}$ & $\begin{array}{l}\text { Maintaining resistance to stresses is desirable for } \\
\text { reducing inputs but some adaptations may be } \\
\text { unnecessary in a human-managed environment. }\end{array}$ & $\begin{array}{l}\text { Many abiotic stresses relaxed using } \\
\text { expensive or non-renewable inputs }\end{array}$ \\
\hline $\begin{array}{l}\text { Enemies limited by polygenic defense } \\
\text { mechanisms and resistance genes }\end{array}$ & $\begin{array}{l}\text { Disease and pest pressures may be higher in large, } \\
\text { high density agricultural stands than in the wild, so } \\
\text { preservation of defense and resistance genes within } \\
\text { the primary gene pool should be prioritized. }\end{array}$ & $\begin{array}{r}\text { Highly reliant on pesticides to limit } \\
\text { enemies. Wide-crossing required to } \\
\text { acquire resistance genes. }\end{array}$ \\
\hline $\begin{array}{l}\text { Smaller, better defended leaves with } \\
\text { high nitrogen and water use efficiency }\end{array}$ & $\begin{array}{l}\text { Both increased seedling growth rate and retention of } \\
\text { resource use efficiency are desirable. }\end{array}$ & $\begin{array}{r}\text { Bigger, thinner leaves with reduced } \\
\text { construction costs, rapid growth }\end{array}$ \\
\hline $\begin{array}{l}\text { Highly dependent upont mutualists } \\
\text { for nutrients }\end{array}$ & $\begin{array}{l}\text { Avoiding breeding in excessively fertile environments } \\
\text { can help maintain efficient mutualisms but } \\
\text { fertilization at specific developmental stages may be } \\
\text { needed for adequate yield. }\end{array}$ & $\begin{array}{l}\text { Dependent upon inputs } \\
\text { and/or tillage for nutrients }\end{array}$ \\
\hline $\begin{array}{l}\text { Pollen and pollinator rewards } \\
\text { abundant }\end{array}$ & $\begin{array}{l}\text { Supporting pollinators is an increasingly valued agro- } \\
\text { ecological service but achieving other domestication } \\
\text { goals may require compromise in floral traits. }\end{array}$ & Few floral resources for pollinators \\
\hline $\begin{array}{l}\text { Seeds, biomass rich in secondary } \\
\text { metabolites with industrial, flavor, or } \\
\text { nutritional value }\end{array}$ & $\begin{array}{l}\text { Selection for increased seed oil, starch, and protein } \\
\text { may reduce the concentration of other phytochemicals } \\
\text { unless they are identified as desirable and selected for. }\end{array}$ & $\begin{array}{r}\text { Low levels of secondary metabolites } \\
\text { in grain and/or biomass }\end{array}$ \\
\hline High genetic diversity & $\begin{array}{l}\text { Relatively few domestication alleles must be fixed but } \\
\text { breeding strategies can minimize unintended allele } \\
\text { loss through hitchhiking or drift. }\end{array}$ & $\begin{array}{l}\text { Low genetic diversity in } \\
\text { primary gene pool }\end{array}$ \\
\hline
\end{tabular}

Fig. 1. Hypothetical stages of de novo domestication of Silphium as an oilseed grain. To avoid developing new crops that are as functionally deficient in ecosystems as our current, annual food and energy crops, recent domestication proposals focus on species with adaptations quite distinct from the ancestors of existing crops (e.g., perennials, halophytes). Rapid improvement of wild candidates (left column) for key domestication traits is required to make these new crops economically viable. Under the hypothetical scenario depicted here, "over-domestication" could occur if strong directional selection for yield traits resulted in the loss of desirable adaptations present in the wild progenitor (right column), through genetic drift or correlated responses to selection. An ideotype designed to deliver a balanced range of crop services (center column) will be a complex mixture of traits: some nearly indistinguishable from annual crops (yellow) and others very close to the fully "wild" state (green). A third set of traits will likely be intermediate between fully wild and fully domesticated (green and yellow), either because a desirable adaptation is "overbuilt" for survival and vigor in a managed ecosystem or because the time and cost required to fully eliminate the wild trait is not justified by the potential benefit. Blended transitions between yellow and green represent our present uncertainty; multidisciplinary collaboration will be required to identify the costs and benefits of modifying each trait. 
The small population should adapt to the local abiotic and biotic conditions, resulting in gradual narrowing of genetic diversity at each site due to genetic drift and selection, but replication across several diverse sites should maintain a broad-genetic base in the crop as a whole. The simplicity of this design enables the participation of researchers with a range of resources, as well as farmers and nonresearch organizations.

\section{Multiple Environments}

Selection for adaptation to multiple environments can ensure that future cultivars can be used across a broad landscape. Advanced materials distributed to collaborators in multiple environments will also be used for genotype-byenvironment studies. Identifying traits correlated with high performance in specific environments will be useful in further refining the ideotype. We expect that GWAS studies can quickly identify major domestication genes or at least markers in linkage disequilibrium with the causal variants (Kruglyak, 2008). Even without knowledge of causal genes or variants, knowledge of these genotype and phenotype (or environmental) associations for Silphium domestication traits should lead to real applications in the form of markerassisted selection strategies, which have been effectively used in many other species, especially in the selection of simple monogenic traits and in pyramiding of major disease resistance genes (Collard and Mackill, 2008).

\section{CONCLUSION}

We are not yet ready to define precise ideotypes for Silphium oilseed, bioenergy, or dual-purpose crops, but this thought experiment has helped us identify areas of research needed to do so (Fig. 1). It also suggests to us that the ideotype concept itself needs to be reinvented. In addition to the more familiar components relating to the classic domestication syndrome and harvest index (Donald and Hamblin, 1983), we suggest that ideotypes for the next generation of new crops need to identify how structural and functional plant features relate to specific ecosystem services, what, if any, are the tradeoffs involved between these characters, what are the genetic bases for these traits, and thus, which selection method should be applied. New ideotypes should also include plans for retaining specific resource-use efficiency, stress toleration, and defensive adaptations during domestication. Achieving any of these goals using breeding necessarily requires the fixation of major-effect "domestication genes" at the plant level and the loss of some genetic diversity from breeding populations, particularly in the case of outcrossing perennials that likely harbor a high level of genetic load. However, the ideotype for the quantity and structure of genetic diversity should extend to the whole crop through strategic partitioning of diversity between populations under different types and levels of selection. Finally, it is now possible to plan for what might be called meta-domestication: the data, narratives, analysis, and biological samples that could allow a domestication event to be analyzed and even replicated experimentally to improve the ideotypes, increase the rate, and reduce the cost of future domestication projects.

\section{References}

Allard, R.W. 1988. Genetic changes associated with the evolution of adaptedness in cultivated plants and their wild progenitors. J. Hered. 79:225-238. doi:10.1093/oxfordjournals.jhered.a110503

Allendorf, F.W., P.A. Hohenlohe, and G. Luikart. 2010. Genomics and the future of conservation genetics. Nat. Rev. Genet. 11:697-709. doi:10.1038/nrg2844

Arkhipenko, F.N., and V.I. Larina. 2011. Cup plant (Silphium perfoliatum L.) in the Ukranian forest steppe. (In Russian.) Plant Introd. 1:9-13.

Asbjornsen, H. 2013. Targeting perennial vegetation in agricultural landscapes for enhancing ecosystem services. Agric. Food Syst. 1:1-25.

Assefa, T.J.W., K.A. Albrecht, P.J. Johnson, and A. Boe. 2015. Genetic variation for biomass and related morphological traits in cup plant (Silphium perfoliatum L.). Am. J. Plant Sci. 6:10981108. doi:10.4236/ajps.2015.68114

Bai, C., W.S. Alverson, A. Follansbee, and D.M. Waller. 2012. New reports of nuclear DNA content for 407 vascular plant taxa. Ann. Bot. (Lond.) 110:1623-1629. doi:10.1093/aob/ $\operatorname{mcs} 222$

Bare, J.E. 1979. Wildflowers and weeds of Kansas. The Regents Press of Kansas, Lawrence.

Baute, G.J., N.C. Kane, C.J. Grassa, Z. Lai, and L.H. Rieseberg. 2015. Genome scans reveal candidate domestication and improvement genes in cultivated sunflower, as well as postdomestication introgression with wild relatives. New Phytol. 206:830-838. doi:10.1111/nph.13255

Benrey, B., A. Callejas, L. Rios, K. Oyama, and R.F. Denno. 1998. The effects of domestication of Brassica and Phaseolus on the interaction between phytophagous insects and parasitoids. Biol. Control 11:130-140. doi:10.1006/bcon.1997.0590

Boeven, P.H., C.F.H. Longin, and T. Würschum. 2016. A unified framework for hybrid breeding and the establishment of heterotic groups in wheat. Theor. Appl. Genet. 129:1231-1245. doi:10.1007/s00122-016-2699-x

Brown, A.H.D. 1989. The case for core collections. In: A.D.H. Brown, D.R. Marshall, O.H. Frankel, and J.T. Williams, editors, The use of plant genetic resources. Cambridge Univ. Press, Cambridge. p. 136-156.

Calus, M.P.L., and R.F. Veerkamp. 2011. Accuracy of multi-trait genomic selection using different methods. Genet. Sel. Evol. 43:26. doi:10.1186/1297-9686-43-26

Cameron, N.D. 1997. Selection indices and prediction of genetic merit in animal breeding. CAB Int., New York.

Clark, L.V., J.E. Brummer, K. Glowacka, M.C. Hall, K. Heo, J. Peng et al. 2014. A footprint of past climate change on the diversity and population structure of Miscanthus sinensis. Ann. Bot. (Lond.) 114:97-107. doi:10.1093/aob/mcu084

Clark, L.V., J. Ryan Stewart, A. Nishiwaki, Y. Toma, J.B. Kjeldsen, U.J. Argensen et al. 2015. Genetic structure of Miscanthus sinensis and Miscanthus sacchariflorus in Japan indicates a gradient of bidirectional but asymmetric introgression. J. Exp. Bot. 66:4213-4225. doi:10.1093/jxb/eru511 
Clevinger, J.A., and J.L. Panero. 2000. Phylogenetic analysis of Silphium and subtribe Engelmanniinae (Asteraceae: Heliantheae) based on ITS and ETS sequence data. Am. J. Bot. 87:565-572. doi:10.2307/2656600

Collard, B.C.Y., D.J. Mackill. 2008. Marker-assisted selection: An approach for precision plant breeding in the twenty-first century. Philos. Trans. R. Soc., B 363:557-572. doi:10.1098/ rstb.2007.2170

Cowling, W.A., B.J. Buirchell, and D.E. Falk. 2009. A model for incorporating novel alleles from the primary gene pool into elite crop breeding programs while reselecting major genes for domestication or adaptation. Crop Pasture Sci. 60:10091015. doi:10.1071/CP08223

Crews, T.E., J. Blesh, S.W. Culman, R.C. Haye, E. Steen Jensen, M.C. Mack et al. 2016. Going where no grains have gone before: From early to mid-succession. Agric. Ecosyst. Environ. 223:223-238. doi:10.1016/j.agee.2016.03.012

Crews, T.E., and L.R. DeHaan. 2015. The strong perennial vision: A response. Agroecol. Sustainable Food Syst. 39:500-515. doi :10.1080/21683565.2015.1008777

DeHaan, L.R., and D.L. Van Tassel. 2014. Useful insights from evolutionary biology for developing perennial grain crops. Am. J. Bot. 101:1801-1819. doi:10.3732/ajb.1400084

DeHaan, L.R., D.L. Van Tassel, J.A. Anderson, S.R. Asselin, R. Barnes, G.J. Baute et al. 2016. A pipeline strategy for grain crop domestication. Crop Sci. 56:917-930. doi:10.2135/cropsci2015.06.0356

DeHaan, L.R., D.L. Van Tassel, and T.S. Cox. 2005. Perennial grain crops: A synthesis of ecology and plant breeding. Renew. Agric. Food Syst. 20:5-14. doi:10.1079/ RAF200496

Desta, Z.A., and R. Ortiz. 2014. Genomic selection: Genomewide prediction in plant improvement. Trends Plant Sci. 19(9):592-601. doi:10.1016/j.tplants.2014.05.006

Dhillion, S.S., and C.F. Friese. 1992. The occurrence of mycorrhizas in prairies: Application to ecological restoration. In: R.G. Wickett et al., editors, Proceedings of the 13th North American Prairie Conference, Windsor, ON. 6-9 Aug. 1992. Dep. of Parks and Recreations, Windsor, ON. p. 103114.

Diamond, J. 2002. Evolution, consequences and future of plant and animal domestication. Nature 418:700-707. doi:10.1038/ nature 01019

Donald, C.M., and J. Hamblin. 1983. The convergent evolution of annual seed crops in agriculture. Adv. Agron. 36:97-143. doi:10.1016/S0065-2113(08)60353-3

Esquinas-Alcázar, J. 2005. Science and society: Protecting crop genetic diversity for food security: Political, ethical and technical challenges. Nat. Rev. Genet. 6:946-953. doi:10.1038/ nrg1729

Ferchaud, F., G. Vitte, and B. Mary. 2016. Changes in soil carbon stocks under perennial and annual bioenergy crops. GCB Bioenergy 8:290-306. doi:10.1111/gcbb.12249

Fiedler, A.K., and D.A. Landis. 2007. Attractiveness of Michigan native plants to arthropod natural enemies and herbivores. Environ. Entomol. 36:751-765. doi:10.1093/ ee/36.4.751

Fontanesi, L., E. D'Alessandro, E. Scotti, L. Liotta, A. Crovetti, V. Chiofalo, and V. Russo. 2010. Genetic heterogeneity and selection signature at the KIT gene in pigs showing different coat colours and patterns. Anim. Genet. 41:478-492. doi:10.1111/j.1365-2052.2010.02054.x
Friesen, P.C., M. de Melo Peixoto, D.K. Lee, and R.F. Sage. 2015. Sub-zero cold tolerance of Spartina pectinata (prairie cordgrass) and Miscanthus $\times$ giganteus: Candidate bioenergy crops for cool temperate climates. J. Exp. Bot. 66:4403-4413. doi:10.1093/jxb/erv085

Gansberger, M., L.F.R. Montgomery, and P. Liebhard. 2015. Botanical characteristics, crop management and potential of Silphium perfoliatum L. as a renewable resource for biogas production: A review. Ind. Crops Prod. 63:362-372. doi:10.1016/j.indcrop.2014.09.047

Glover, J.D., J.P. Reganold, L.W. Bell, J. Borevitz, E.C. Brummer, E.S. Buckler et al. 2010. Increased food and ecosystem security via perennial grains. Science 328:1638-1639. doi:10.1126/ science. 1188761

González-Paleo, L., and D.A. Ravetta. 2011. Indirect changes associated with a selection program for increased seed-yield in wild species of Lesquerella (Brassicaceae): Are we developing a phenotype opposite to the expected ideotype? Ind. Crops Prod. 34:1372-1380. doi:10.1016/j.indcrop.2010.12.006

González-Paleo, L., and D.A. Ravetta. 2012. Allocation patterns and phenology in wild and selected accessions of annual and perennial Physaria (Lesquerella, Brassicaceae). Euphytica 186:289-302. doi:10.1007/s10681-011-0542-7

González-Paleo, L., A.E. Vilela, and D.A. Ravetta. 2016. Back to perennials. Does selection enhance tradeoffs between yield and longevity? Ind. Crops Prod. 91:272-278. doi:10.1016/j. indcrop.2016.07.018

Han, K.J., K.A. Albrecht, D.R. Mertens, and D.A. Kim. 2000a. Comparison of in vitro digestion kinetics of cup plant and alfalfa. Asian-Aus. J. Anim. Sci. 13:641-644.

Han, K.J., K.A. Albrecht, R.E. Muck, and D.A. Kim. 2000b. Moisture effects on fermentation characteristics of cup plant silage. Asian-Aus. J. Anim. Sci. 13:636-640.

Harfouche, A., R. Meilan, M. Kirst, M. Morgante, W. Boerjan, M. Sabatti et al. 2012. Accelerating the domestication of forest trees in a changing world. Trends Plant Sci. 17:64-72. doi:10.1016/j.tplants.2011.11.005

Haussmann, B.I.G., H.K. Parzies, T. Presterl, Z. Susic, and T. Miedaner. 2004. Plant genetic resources in crop improvement. Plant Genet Resour. 2:3-21. doi:10.1079/PGR200430

Heffner, E.L., A.J. Lorenz, J.L. Jannink, and M.E. Sorrells. 2010. Plant breeding with genomic selection: Gain per unit time and cost. Crop Sci. 50:1681-1690. doi:10.2135/cropsci2009.11.0662

Henry, R.J. 2012. Next-generation sequencing for understanding and accelerating crop domestication. Briefings Funct. Genomics 11:51-56. doi:10.1093/bfgp/elr032

Jamiolkowska, A., and R. Kowalski. 2012. In vitro estimate of influence of Silphium perfoliatum L. leaves extract on some fungi colonizing the pepper plants.. R. Acta Sci. Pol. 11:4355.

Jia, Y., and J.L. Jannink. 2012. Multiple-trait genomic selection methods increase genetic value prediction accuracy. Genetics 192:1513-1522. doi:10.1534/genetics.112.144246

Johnson, P., A. Boe, K. Albrecht, and V.C. Torrez. 2012. Recent discoveries and development in the entomology of bioenergy crop production. In: Proceedings of the 2012 Sun Grant National Conference, New Orleans, LA. 2-5 Oct. 2012. Univ. of Tennessee, Knoxville. p. 4.

Juenger, T.E. 2013. Natural variation and genetic constraints on drought tolerance. Curr. Opin. Plant Biol. 16:274-281. doi:10.1016/j.pbi.2013.02.001 
Kantar, M., C. Tyl, K. Dorn, X. Zhang, J. Jungers, J.M. Kaser et al. 2016. Perennial grain and oilseed crops. Annu. Rev. Plant Biol. 67:703-729. doi:10.1146/annurevarplant-043015-112311

Kowalski, R., and J. Wiercinski. 2004. Evaluation of chemical composition of some Silphium L. species seeds as alternative foodstuff raw materials. Pol. J. Food Nutr. Sci. 13:349-354.

Koziol, L., and J. Bever. 2015. Mycorrhizal response trades off with plant growth rate and increases with plant successional status. Ecology 96:1768-1774. doi:10.1890/14-2208.1

Kruglyak, L. 2008. The road to genome-wide association studies. Nat. Rev. Genet. 9:314-318. doi:10.1038/nrg2316

Kula, R.R., P.J. Johnson, T.T. Heidel-Baker, and A. Boe. 2017. A new species of Acanthocaudus Smith (Braconidae: Aphidiinae), with a key to species and new host and distribution records for aphidiines assoiated with Silphium perfoliatum L. (Asterales: Asteraceae). Zootaxa 4236:543-552.

Ladizinsky, G. 1985. Founder effect in crop-plant evolution. Econ. Bot. 39:191-199. doi:10.1007/BF02907844

Lehmkuhler, J.W., M.H. Ramos, and K.A. Albrecht. 2007. Cup plant silage as a replacement for corn silage in beef cattle diets. Forage and Grazinglands 5(1):1-6. doi:10.1094/FG-20071107-01-RS

Leopold, A. 1968. A Sand County almanac. 2nd ed. Oxford Univ. Press, Oxford, UK.

Lynch, J.p. 2013. Steep, cheap and deep: An ideotype to optimize water and $\mathrm{N}$ acquisition by maize root systems. Ann. Bot. (Lond.) 112:347-357. doi:10.1093/aob/mcs293

Mandel, J.R., S. Nambeesan, J.E. Bowers, L.F. Marek, D. Ebert, L.H. Rieseberg et al. 2013. Association mapping and the genomic consequences of selection in sunflower. PLoS Genet. 9:e1003378. doi:10.1371/journal.pgen.1003378

Meilleur, B.A., and T. Hodgkin. 2004. In situ conservation of crop wild relatives : Status and trends. Biodivers. Conserv. 13:663684. doi:10.1023/B:BIOC.0000011719.03230.17

National Plant Data Team. 2016. The plant database. USDANRCS. http://plants.usda.gov (accessed 20 Sept. 2016).

Ouyang, K., K. Wang, D. Li, Z. Li, and B. Liu. 2007. Establishment of sown pastures in the hilly red soil region of the subtropics in southern China. Trop. Grassl. 41:92-99.

Pavek, D.S., W.F. Lamboy, and E.J. Garvey. 2003. Selecting in situ conservation sites for grape genetic resources in the USA. Genet. Resour. Crop Evol. 50:165-173. doi:10.1023/A:1022947605916

Pestsova, E. 2015. Silphium perfoliatum resource evaluation and development (SPREAD). Bioeconomy Science Center. http://www.biosc.de/spread (accessed 28 Sept. 2016).

Power, A.G. 2010. Ecosystem services and agriculture: Tradeoffs and synergies. Philos. Trans. R. Soc. Lond. B Biol. Sci. 365:2959-2971. doi:10.1098/rstb.2010.0143

Prasifka, J.R., D.K. Lee, J.D. Bradshaw, A.S. Parrish, and M.E. Gray. 2012. Seed reduction in prairie cordgrass, spartina pectinata Link., by the floret-feeding caterpillar Aethes spartinana (Barnes and McDunnough). BioEnergy Res. 5:189-196. doi:10.1007/s12155-011-9120-z

Prezeworski, M., G. Coop, and J.D. Wall. 2005. The signature of positive selection on standing genetic variation. Evolution 59:2312-2323. doi:10.1111/j.0014-3820.2005. tb00941.x

Raymer, P.L. 2002. Canola: An emerging oilseed crop. In: J. Janick and A. Whipkey, editors, Trends in new crops and new uses. ASHS Press, Alexandria, VA. p. 122-126.
Rellstab, C., F. Gugerli, A.J. Eckert, A.M. Hancock, and R. Holderegger. 2015. A practical guide to environmental association analysis in landscape genomics. Mol. Ecol. 24:4348-4370. doi:10.1111/mec.13322

Resende, M.D.V., M.F.R. Resende, Jr., C.P. Sansaloni, C.D. Petroli, A.A. Missiaggia, A.M. Aguiar et al. 2012. Genomic selection for growth and wood quality in Eucalyptus: Capturing the missing heritability and accelerating breeding for complex traits in forest trees. New Phytol. 194:116-128. doi:10.1111/ j.1469-8137.2011.04038.x

Reyno, R., R. Narancio, P. Speranza, J. Do Canto, B. LópezCarro, P. Hernández et al. 2012. Molecular and cytogenetic characterization of a collection of bahiagrass (Paspalum notatum Flügge) native to Uruguay. Genet. Resour. Crop Evol. 59:1823-1832. doi:10.1007/s10722-012-9806-x

Rodriguez-Saona, C., N. Vorsa, A.P. Singh, J. Johnson-Cicalese, Z. Szendrei, M.C. Mescher, and C.J. Frost. 2011. Tracing the history of plant traits under domestication in cranberries: Potential consequences on anti-herbivore defenses. J. Exp. Bot. 62:2633-2644. doi:10.1093/jxb/erq466

Rozema, J., and T. Flowers. 2008. Crops for a salinized world. Science 322:1478-1480. doi:10.1126/science.1168572

Runck, B.C., M.B. Kantar, N.R. Jordan, J.A. Anderson, D.L. Wyse, J.O. Eckberg et al. 2014. The reflective plant breeding paradigm: A robust system of germplasm development to support strategic diversification of agroecosystems. Crop Sci. 54:1939-1948. doi:10.2135/cropsci2014.03.0195

Sanderson, M.A., and P.R. Adler. 2008. Perennial forages as second generation bioenergy crops. Int. J. Mol. Sci. 9:768-788. doi:10.3390/ijms9050768

Saxena, K.B., and S.L. Sawargaonkar. 2014. First information on heterotic groups in pigeonpea [Cajanus cajan (L.) Millsp.]. Euphytica 200:187-196. doi:10.1007/s10681-014-1142-0

Schoo, B., K.P. Wittich, U. Böttcher, H. Kage, and S. Schittenhelm. 2016. Drought tolerance and water-use efficiency of biogas crops: A comparison of cup plant, maize and lucerne-grass. J. Agron. Crop Sci. 203:117-130. doi:10.1111/jac.12173

Schorpp, Q., and S. Schrader. 2016. Earthworm functional groups respond to the perennial energy cropping system of the cup plant (Silphium perfoliatum L.). Biomass Bioenergy 87:61-68. doi:10.1016/j.biombioe.2016.02.009

Seifert, E.K., J.D. Bever, and J.L. Maron. 2009. Evidence for the evolution of reduced mycorrhizal dependence during plant invasion. Ecology 90:1055-1062. doi:10.1890/08-0419.1

Settle, W.J. 1967. The chromosome morphology in the genus Silphium (Compositae). Ohio J. Sci. 67:10-19.

Shapter, F.M., M. Cross, G. Ablett, S. Malory, I.H. Chivers, G.J. King, and R.J. Henry. 2013. High-throughput sequencing and mutagenesis to accelerate the domestication of Microlaena stipoides as a new food crop. PLoS ONE 8:e82641. doi:10.1371/ journal.pone.0082641

Sharma, H.C., J.H. Crouch, K.K. Sharma, N. Seetharama, and C.T. Hash. 2002. Applications of biotechnology for crop improvement: Prospects and constraints. Plant Sci. 163:381395. doi:10.1016/S0168-9452(02)00133-4

Simmonds, N.W. 1962. Variability in crop plants, its use and conservation. Biol. Rev. Camb. Philos. Soc. 37:422-465. doi:10.1111/j.1469-185X.1962.tb01620.x

Simmonds, N.W. 1993. Introgression and incorporation: Strategies for the use of crop genetic resources. Biol. Rev. Camb. Philos. Soc. 68:539-562. doi:10.1111/j.1469-185X.1993.tb01243.x 
Smaje, C. 2015. The strong perennial vision: A critical review. Agroecol. Sustainable Food Syst. 39:471-499. doi:10.1080/21 683565.2015.1007200

Stanford, G. 1990. Silphium perfoliatum (cup-plant) as a new forage. In: D.D. Smith and C.A. Jacobs, editors, Proceedings of the 12th North American Prairie Conference, Cedar Falls, IA. 5-9 Aug. 1990. Univ. of Northern Iowa, Cedar Falls. p. $33-37$

The Plant List. 2013. The plant list. Version 1.1. http://www.theplantlist.org (accessed 10 Sep. 2016).

Tuell, J.K., A.K. Fiedler, D. Landis, and R. Isaacs. 2008. Visitation by wild and managed bees (Hymenoptera: Apoidea) to Eastern U. S. native plants for use in conservation programs. Environ. Entomol. 37:707-718. doi:10.1603/0046-225X(2008 )37[707:VBWAMB]2.0.CO;2

Van Tassel, D.L., S.R. Asselin, S.A. Cox, G. Sideli, and D.J. Cattani. 2014. Evaluating perennial candidates for domestication: Lessons from wild sunflower relatives. In: C. Batello, L. Wade, S. Cox, N. Pogna, A. Bozzini, and J. Choptiany, editors, Perennial crops for food security. Proceedings of the FAO Expert Workshop. FAO, Rome. p. 112-140.

Van Tassel, D.L., L.R. DeHaan, and T.S. Cox. 2010. Missing domesticated plant forms: Can artificial selection fill the gap? Evol. Appl. 3:434-452. doi:10.1111/j.1752-4571.2010.00132.x

Vico, G., S. Manzoni, K. Murphy, and M. Weih. 2015. Trade-offs between seed output and life span- a quantitative comparison of traits between annual and perennial congeneric species. New Phytol. 209:104-114.

Visscher, P.M., M.A. Brown, M.I. McCarthy, and J. Yang. 2012. Five years of GWAS discovery. Am. J. Hum. Genet. 90:7-24. doi:10.1016/j.ajhg.2011.11.029
Von Gehren, P., M. Gansberger, J. Mayr, and P. Liebhard. 2016. The effect of sowing date and seed pre-treatments on establishment of the energy plant Silphium perfoliatum L. by sowing. Seed Sci. Technol. 44:310-319. doi:10.15258/sst.2016.44.2.04

Weaver, J.E., L.a. Stoddart, and W. Noll. 1935. Response of the prairie to the great drought of 1934. Ecology 16:612-629. doi:10.2307/1932592

Wright, S.I., I.V. Bi, S.G. Schroeder, M. Yamasaki, J.F. Doebley, M.D. McMullen, and B.S. Gaut. 2005. The effects of artificial selection on the maize genome. Science 308:1310-1314. doi:10.1126/science.1107891

Wrobel, M., J. Fraczek, S. Francik, Z. Slipek, and M. Krzysztof. 2013. Influence of degree of fragmentation on chosen quality parameters of briquette made from biomass of cup plant Silphium perfoliatum 1. Jelgava 23:653-657.

Wynia, R. 2009. Plant guide for compass plant (Silphium laciniatum L.). USDA-NRCS, Kansas Plant Materials Center, Manhat$\tan , \mathrm{KS}$.

Yatskievych, G. 2006. Steyermark's flora of Missouri. Vol. 2. Revised ed. Missouri Botanical Garden Press, St. Louis, MO.

Zhang, H., Z. Shen, G. Yang, Z. An, and Q. Sun. 2011. Effect of chicken manure-amended copper mine tailings on growth of compositae Silphium perfoliatum and substrate properties. Xi Nan Nong Ye Xue Bao 24:1792-1798.

Zhang, Q., Q. Zhou, L. Ren, Y. Zhu, and S. Sun. 2006. Ecological effects of crude oil residues on the functional diversity of soil microorganisms in three weed rhizospheres. J. Environ. Sci. (China) 18:1101-1106. doi:10.1016/S1001-0742(06)60046-6 